\title{
JUDICIAL REVIEW SATU ATAP DI MAHKAMAH KONSTITUSI SEBAGAI REFLEKSI TERHADAP PROBLEMATIKA DAN TANTANGAN KEKUASAAN KEHAKIMAN DI INDONESIA
}

\author{
Moh. Ali Hofi \\ Prodi Hukum, Fakultas Ilmu Sosial dan Humaniora, \\ Universitas Ibrahimy, Situbondo Jawa Timur \\ Email: muhammadalihofi@gmail.com
}

\begin{abstract}
Abstraks
Judicial review merupakan suatu upaya hukum agar dapat keluar dari peroalan regulasi yang dihasilkan pembentuk uu dengan kualitas rendah. namun demikian, penyelenggaraan judicial review pada praktiknya selama ini dapat memunculkan suatu persoalan hukum. Penyebabnya di antaranya adalah pembagian kewenangan dalam praktik judicial review oleh MK dan MA untuk melakukan judicial review. Disamping hal di atas, beberapa alasan pengujian satu atap di Mahkamah Konstitusi didasari beberapa alasan, di antaranya mengurungi beban menumpuk di Mahkamah Agung mengingat MA tidak hanya sekedar menguji regulasi dibawah uu, kasasi, peninjauan kembali kasus pidana dan perdata serta TUN juga menjadi bagian dari kewenangan MA yang tidak terpisahkan, kepastian hukum serta keadilan bagi masyarakat, efisiensi dan efektifitas dapat diwujudkan bila dilakukan dalam satu atap di MK. Praktik judicial review di Mahkamah Konstitusi sangat terbuka bila di bandingkan MA. Karenanya judicial review satu di MK Urgent untuk dilaksanakan. Tulisan ini mengkaji dengan konkrit persoalan dualisme judicial review dalam perspektif negara hukum serta ugensi judicial review satu pintu di MK sebagai solusi atas problematika di atas.
\end{abstract}

Kata Kunci : Dualisme judicial review, satu atap, Mahkamah Konstitusi.

\begin{abstract}
Judicial review is a legal effort to get out of regulatory problems produced by lawmakers with low quality. however, the implementation of a judicial review in practice so far can raise a legal problem. One of the reasons is the division of authority in the practice of judicial review by the Constitutional Court and the Supreme Court to conduct a judicial review. In addition to the above, several reasons for the one-stop testing at the Constitutional Court are based on several reasons, including reducing the burden piled up on the Supreme Court considering
\end{abstract}


that the Supreme Court is not only testing regulations under the law, cassation, review of criminal and civil cases and TUN are also part of the authority. The Supreme Court is inseparable, legal certainty and justice for the community, efficiency and effectiveness can be realized if carried out under one roof in the Constitutional Court. The practice of judicial review in the Constitutional Court is very open when compared to the Supreme Court. Therefore, a judicial review in the Constitutional Court is urgent to be carried out. This paper examines the issue of judicial review dualism in a state of law perspective and the urgency of a one-stop judicial review in the Constitutional Court as a solution to the above problems.

Keywords : Dualism judicial review, one roof, Constitutional Court.

\section{PENDAHULUAN}

\section{A. Latar Belakang}

Perubahan UUD 1945 melahirkan MK sebagai lembaga tinggi dalam praktik ketatanegaraan. ${ }^{1}$ Lembaga di atas di dirikan sebagai pengawal, penafsir dan penguji uu terhadap UUD 1945. Pada praktiknya, MK mengusung visi menegakkan konstitusi agar tercipta sebuah negara hukum yang berlandaskan demokrasi demi martabat bangsa dan negara".2 Atas dasar visi tersebutlah MK menjalankan Praktik peradilan dengan amanah Pasal 24C UUD $1945 .^{3}$

Pasal 24C (1), (2), uu No. 24/2003 sebagaimana telah diubah dengan UU No. 7/2020 tentang MK sebagai dasar hukum berdiri dan berpraktiknya MK dalam kekuasaan kehakiman. Berdirinya MK sebagai pengawal konstitusi tidak serta merta dimanfaatkan dengan baik oleh pencari keadilan yang haknya di diskriminasi dengan berlakunya suatu uu. Namun seiring berkembangnya praktik ketatanegaraan MK telah banyak menerima, memproses dan kemudian memutus perkara yang merupakan bagian dari kewenanganya. ${ }^{4}$ Kurun waktu 16 (enam belas) tahun MK telah memtus 3225 putusan dengan persentase PUU sebanyak 1401 perkara, (43\%), SKLN 26 kasus (1\%), PHPU 676 perkara (21\%), dan PHPKADA 1122 kasus (35\%). ${ }^{5}$

1 Bambang Sutiyoso. Pembentukan Mahkamah Konstitusi Sebagai Pelaku Kekuasaan Kehakiman di Indonesia Jurnal Konstitusi, Volume 7, Nomor 6, Desember 2010. h, 2

${ }^{2}$ Ibid,

3 Prakata dalam Home Page Mahkamah Konstitusi Republik Indonesia, http://www. mahkamahkonstitusi.go.id/ diakses 1 Oktober 2021

4 Bambang Sutiyoso. Pembentukan Mahkamah Konstitusi Sebagai Pelaku Kekuasaan Kehakiman di Indonesia Jurnal Konstitusi, Volume 7, Nomor 6, Desember 2010. h. 3

${ }^{5}$ http://www.mahkamahkonstitusi.go.id/

\section{HUKMY|Jurnal Hukum}


Kembali ke konsep praktik kewenangan judicial review di Indonesia, secara absolut tidak memberi kewenangan hanya kepada MK, namun MA juga berwenang untuk melakukan judicial review. ${ }^{6}$ Judicial review adalah media kontrol sebuah regulasi yang di hasilkan oleh pejabat yang berwenang dengan kualitas tidak baik dan condong merugikan hak masyarakat. Praktik judicial review yang tengah berlangsung saat ini berpotensi menimbulkan persoalan hukum baru. Putusan yang di hasilkan MK serta MA terjadi pertentangan ketika memahami dan memutus isu hukum yang berakibat adanya ketidakpastian dan keadilan bagi masyarakat.

Beberapa kasus dari persoalan di atas, putusan kasasi MA No 1.110/K/Pid.Sus/2012 terkait dengan (Tipikor),putusan tersebut MA menjadi dasar hukum yang sudah diputuskan tidak berlaku oleh MK. Kemudian persoalan mengenai legalitas calon DPD yang berangkat dari parpol. Dalam kasus ini putusan MK dan MK sangat jelas bertolak belakang. PMK No. 30/PUU-XVI/2018 pengurus atau anggota parpol tidak dapat menjadi calon anggota DPD, disisi lain PMA No. 65 P/HUM/2018 memutuskan bahwa anggota serta pengurus partai dapat menjadi calon anggota DPD di pemilu 2019. Perkara yang sama dengan putusan yang berbeda bukan saja bertentangan dengan adanya kepastian hukum namun juga tidak baik dalam praktik ketatanegaraan. Persoalan berikutnya yang dapat saja terjadi dengan dualisme ini adalah terkait dengan subjek batu uj dari regulasi yang ada. Bisa jadi suatu peraturan tidak bertentangan dengan uu di atasnya, namun bila dikaji lebih jauh ia dapat bertentangan dengan UUD 1945 sebagai norma hukum tertinggi. Oleh sebab itu satu atap dengan satu batu uji uu di MK akan sangat efektif dan efisien.

Judicial review adalah sebuah gagasan modern dalam negara demokratis. yang bertujuan tidak adanya perbuatan semena-mena dari penguasa (abuse of power) pejabat negara, dan menjamin terselenggaranya fungsi eksekutif, legislatif, dan yudikatif berjalan dengan sebagaimana seharusnya, lalu, Melindungi dan menjamin setiap masyarakat terhindar dari penyalahgunaan kewenangan yang berakibat pada terjadinya diskriminasi pada hak warga negara. Terjadinya problematika hukum

6 Tenri Wulan Aris, Urgensi Judicial Review Satu Atap Oleh Mahkamah Konstitusi. de Jure; Jurnal Ilmiah Ilmu Hukum . Vol. 1 No. 2 Juni (2020) : 142-152 ISSN Print: 2715-9531. ISSN Online: 2716-0467. h, 141 
antara MK maupun MA dapat terus terjadi ke depan jika dualism judicial review tetap dipertahankan dalam praktik ketatanegaraan. Perbedaan putusan yang kontradiktif sangat mungkin terulang dalam praktik anatar dua lembaga di atas jika pandangan dan analisis terhadap suatu perkara yang di gunakan berbeda satu dan lainnya.

\section{B. Batasan Masalah}

Artikel ini difokuskan untuk mengkaji dengan konkrit persoalan dualisme judicial review dalam perspektif negara hukum serta ugensi bentuk ideal judicial review satu pintu di MK sebagai solusi atas problematika di atas. Tulisan ini bertujuan untuk mengurai dan menganalisis persoalan atau konflik norma yang terjadi dalam praktik dualisme pengujian uu serta untuk menemukan formasi hukum yang tepat dalam mengatasi persoalan di atas dengan dilaksanakannya judicial review satu atap di Mahkamah Konstitusi.

\section{Motode Penelitian}

Artikel ini menggunakan tipe penelitian hukum normatif dengan metode pengumpulan bahannya adalah studi dokumen (documentary study). bahan hukum utama berupa regulasi-regulasi yang terkait dengan judul artikel ini antara lain, UUD 1945, UU, PMK, PP serta uu lain yang erat kaitannnya dengan objek penelitian. bahan hukum pendukung berupa buku, jurnal hukum, media informasi, dan karya ilmiah hukum.

\section{PEMBAHASAN}

\section{Persoalan Praktik Dualisme Judicial Review di Indonesia}

Judicial review dapat dimaknai sebagai suatu konsep guna menguji sebuah peraturan yang dilaksanakan lembaga peradilan (MK). Arti kata judicial diartikan suatu kewenangan lembaga peradilan yang cakupannya sangat luas karena tidak hanya terkait dengan konstitusionalitas apa yang di uji. Namun erat kaitannya dengan suatu legalitas yang berpedoman pada UUD $1945 .^{7}$ Judicial review adalah wewenang yang melekat pada suatu lembaga dalam ranah kekuasaan kehakiman guna menguji kesahan dan kekuatan berlakunya produk hukum hasil pembahasan bersama antara legislatif dan pemerintah. Pengujian suatu UU oleh hakim terhadap hasil kekuasaan pemerintah

7 Jimlly Ashiddiqie, (2005), Model-Model Pengujian Konstitusional Di Berbagai Negara, Jakarata: Konstitusi Press. h, 3

\section{HUKMY|Jurnal Hukum}


dan legislatif adalah satu konsekuensi hukum atas prinsip check and balances yang berangkat dari teori pembagian kekuasaan. ${ }^{8}$

Oleh sebab itu, melekat pada hakim kewenangan guna menguji suatu uu sesuai dengan fungsi daripada hakim itu sendiri yang bertindak sebagai subjek, tidak pada lembaga atau pejabat lain diluar hakim. Jika legislatif yang menguji maka disebuat dengan legislative review. Jika pemerintah yang melakukan hal tersebut maka hal ini dinamakan executive review sedangkan fokus kajian ini adalah judicial review yang dilaksanakan oleh yang mulia yakni hakim. ${ }^{9}$

Dengan sistem hukum Indonesia praktik Judicial review di bagi dan dilaksanakan oleh MK dan MA dengan masing-masing mengacu pada ketentuan Pasal 24A (1) UUD 1945 tentang tugas dan kewenangan MA, Pasal 24C (1) UUD 1945 mengatur tentang tugas, fungsi dan kewajiban MK yang salah satu dari kewenangan MK adalah menguji uu yang diajukan oleh pemohon karena ada anggapan bertentangan dengan konstitusi (UUD 1945 dan sekaligus UUD 1945 sebagai batu uji MK dalam memutus perkara yang menjadi kewenangannya. ${ }^{10}$

Jika melihat mencermati uraian di atas dalam kaitannya dengan praktik judicial review antara MK dan MA, maka keduanya ditemukan beberapa perbedaan dalam hal bahan yang di ujinya. UU No 15/2019 sebagai perubahan dari UU No. 12/2011 tentang PPP yang mengatur jenis dan hierarki perundang-undangan dalam hal terdapat praktik judicial review atas produk hukum tersebut di atas, dengan adanya ketentuan pasal tersebut, maka jelas disitu terdapat ketentuan mana yang menjadi ranah daripada MK dan pada bagian uu mana MA berwenangan menerima dan melakukan judicial review. ${ }^{11}$

Keberadaan MK dan MA secara konstitusi berwenang menyelenggarakan praktik judicial, pada tataran praktik di dunia nyata putusan-putusan yang di hasilkan oleh kedua lembaga tadi tidak hanya berpotensi menimbulkan perbedaan dan problematika hukum namun juga dapat menjadikan keadilan sukar ditemukan dalam putusan-

\footnotetext{
${ }^{8}$ Abdul Mukthie Fadjar,(2006), Hukum Konstitusi Dan Mahkamah Konstitusi, Cetakan Pertama, Jakarta: Konstitusi Press dan Citra Media, h, 34-35

${ }^{9}$ Tenri Wulan Aris, Urgensi Judicial Review Satu Atap Oleh Mahkamah Konstitusi. de Jure; Jurnal Ilmiah Ilmu Hukum . Vol. 1 No. 2 Juni (2020) : 142-152 ISSN Print: 2715-9531. ISSN Online: 2716-0467. h, 145

${ }^{10}$ Ibid,

11 Ibid,
} 
putusan tersebut. Pada intinya prinsip judicial review oleh dua lembaga berbeda dapat dipastikan memunculkan persoalan hukum baru. ${ }^{12}$

Dualisme judicial review antara MK dan MA dapat menghasilkan persoalan hukum baru meski dengan jenjang norma yang berbeda, tidak hanya pada tataran teknis namun pada sistem hukum kita menggunakan teori stufenbau theory, maksudnya asas lex superior dan derogat lex inferior asas tersebut menuntut setiap peraturan berada pada satu garis yang sama dari yang rendah hingga yang paling tinggi, namun dengan hadirnya dua lembaga berbeda yang menguji peraturan tersebut menjadi aneh tapi nyata dan kenyataan itu berpotensi menimbulkan hasil yang berbeda karena di lakukan dalam dua atap yang berbeda dalam menguji kesahan dan daya berlakunya. ${ }^{13}$ Dengan tolak ukur yang berda sebagai batu dari lembaga di atas, maka dapat dipastikan putusan hukum yang di hasilkan juga akan berbeda dan potensian sekali menimbulkan ketidakpastian dan keadilan hukum. Dalam Negara hukum tentunya hal semacam ini tidak bisa dibiarkan berlarut lama karena dapat menimbulkan kekaburan norma.

Secara Global dalam kaitannya dengan judicial review dikenal 2 (dua) praktik, yakni centralised system merupakan suatu pengujian di praktikkan serta terfokus pada lembaga tunggal saja, bisa pada MK ataupun MA misalnya atau lembaga khusus bila ada dan memungkinkan. Kedua yaitu decentralised system yang kedua disini hampir sama dengan yang di praktikkan di Indonesia yang tidak terfokus pada satu badan saja. ${ }^{14}$ Praktik decentralised system terjadi di Amerika Serikat, MA di As peradilan di bawahnya juga berwenang menerima, memeriksa dan memutus permohonan judicila review. Perlu dipahami bahwa sekalipun lembaga atau badan dibawah MA As juga melakukan judicial review namun semua lembaga tersebut bernaung dalam satu atap atau satu pintu di MA Amerika Serikat. Jadi, putusan yang dihasilkan oleh badan dibawah MA bisa dilakukan peninjauan kembali pada peradilan di atasnya sehingga tidak memunculkan konflik norma baru akibat adanya putusan tersebut disamping hal itu semua putusan berada dalam pengawasan MA Amerika dengan demikian dapat terjamin adanya kepastian dan keadilan.

\footnotetext{
12 Ni'matul Huda, (2018), Kekuatan Eksekutorial Putusan Mahkamah Konstitusi, Cetakan Pertama, Yogyakarta: FH UII Press, h, 2

13 Badan Pembinaan Hukum Nasional Kementerian Hukum dan HAM RI, Pengkajian Konstitusi Tentang Problematika Pengujian Peraturan Perundang Undangan, (Jakarta: Tim Pengkajian Konstitusi Tentang Problematika Pengujian Peraturan Perundang-Undangan), h, 30-31

14 Jimly Assihiddiqie,(2006), Perihal Undang-Undang, Kepanitraan MKRI, h, 7
}

\section{HUKMY|Jurnal Hukum}


Kembali pada konsep judicial review yang menjadi bagian dari terwujudnya keseimbangan atau checks and balances yang menjadikan seluruh lembaga negara berada di posisi yang sama, sehingga bisa saling mengontrol dan mengimbangi anatar lembaga tersebut dalam hal penyelenggaraan pemerinatahan. Bekerjanya praktik checks and balances dicirikan dengan lahirnya putusan dalam perkara judicial review yang diterima oleh semua badan dan lembaga, dengan kata rtinya lain putusan tadi tidak terjadi konflik hukum.

Secara teknis persoalan hukum yang bisa saja terjadi bila praktik judicial review masih dilakukan dalam dua pintu yakni di MA dan MK, disamping persoalan batu uji sebagai bahan acuan, maka terdapat beberapa permasalahan lain yang terjadi pada praktiknya selama ini yang terjadi di MA, diantara masalah tersebut adalah, ${ }^{15}$ pertama, persoalan prosedur pemeriksaan perkara yang dilakukan dengan tidak menged epankan asas transparansi dan hukum acaranya yang tidak terstruktur dengan jelas menjadikan judicial review pada MA tidak jarang menjadi sorotan hingga kritikan datang dari mereka yang berusaha menemukan keadilan di MA.

Kritikan tersebut bukan tidak berdasar, persidangan di MA dinyatakan terbuka bagi umum, namun praktiknya justru tidak demikian karena dalam proses pemiriksaan para pihak tidak wajib menghadirinya. Kemudian pemeriksaan saksi dari para pemohon tidak pula di hadirkan langsung, demikian pula dengan keterangan ahli keterangnya didengarkan melalui tulisan. Praktik persidangan di MA teknisnya hanya dititikberatkan pada berkas yang di ajukan pemohon dan nota jawaban dari termohon. Sedangkan Mahkamah Konstitusi dalam persidangnnya mengacu pada konsep audi et alteram partem, ${ }^{16}$ yakni kedua pihak dihadirkan untuk di dengar keterangan dan pendapatnya oleh hakim agar menemukan fakta hukum di persidangan. Dengan praktik persidangan demikian di MA yang terasa begitu prosedural sehingga terkesan tidak progresif di Mahkamah Konstitusi. ${ }^{17}$

\footnotetext{
15 Janpatar Simamora, (2013),Analisis Yuridis Terhadap Model Kewenangan Judicial Review Di Indonesia, Fakultas Hukum Universitas HKBP Nommensen, Vol.25, No.3, Oktober, h, 310

16 Maftuh Effendi,(2013), Kewenangan Uji Materill Peraturan Perundang-Undangan di Bawah UndangUndang, Jakarta: Pusat Penelitian dan Pengembangan Mahkamh Agung RI, h. 46

17 Ibid,
} 
Disamping alasan yang telah dikemukakan di atas, banyaknya perkara yang dibebankan kepada MA menjadi satu alasan konkrit bahwa mekanisme hukum acara di MA tidak lagi efektif. Pernyataan tersebut disampaikan Ka. Biro Hubungan Masyarakat MA, bahwa kasus yang di hadapi MA sangat banyak, mulai kasasi, PK, dan kasus hukum lainnya. Dengan banyaknya kasus yang ditangani, MA dapat bekerja dengan mengejar target. Hal tersebut menjadi sangat wajar mengingat MA adalah ujung dari seluruh peradilan umum di bawah MA. Karena faktor itulah judicial review bila masih dibebankan pada MA akan semakin menambah pekerjaan dan beban yang bisa berdampak pada praktik peradilan yang tidak efekti. ${ }^{18}$

Lalu yang kedua, dalam tataran teknis, kemajuan dan kecanggihan teknologi tidak serta merta di manfaatkan oleh MA dalam praktik persidangan, berbedang dengan MK yang menjadikan kemajuan teknologi sebagai suatu moment agar praktik peradilan lebih efisien baik dari sisi tempat dan waktu, terbukti MK telah berulang kali dalam praktiknya menyelenggarakan proses peradilan teleconference atau jarak jauh. Dengan teleconference tadi dapat memudahkan pemohon dan termohon khususnya yang letak atau jarak daerahnya jauh dari ibu kota tempat MK melangsungkan persidangan. ${ }^{19}$

Tidak tersedianya prosedur peradilan teleconference di MA, maka hal tersebut dapat menjadi suatu ganjalan bagi masyarakat dalam memperoleh hak keadilannya, sebab, peta geografis dari Indonesia adalah negara kepulauan yang tersebar di beberapa wilayah terpencil. Tidak tersedianya teleconference, serta transparansi yang lemah dalam penyelenggaraan uji materil, dapat dikatakan Pratik pengujian peraturan yang di praktikkan MA sejauh ini melanggar adanya asas independensi, impartial serta peradilan cepat dengan biaya murah.

Dengan memperhatikan uraian di atas dalam kaitannya dengan persoalanpersoalan hukum yang konkrit baik dari sisi kepastian dan keadilan hukumnya, dari tataran teknis pelaksanaanya, maka sudah seharusnya mulai difikirkan adanya formulasi hukum baru dalam praktik judicial review. Sebagai solusi utama atas persoalan di atas, judicial review satu pintu di MK menjadi solusi tepat, di samping menjamin kepastian hukum, keadilan, dan proses peradilan yang lebih transparansi

\footnotetext{
18 Tenri Wulan Aris, Urgensi Judicial Review Satu Atap Oleh Mahkamah Konstitusi. de Jure; Jurnal Ilmiah Ilmu Hukum . Vol. 1 No. 2 Juni (2020) : 142-152 ISSN Print: 2715-9531. ISSN Online: 2716-0467. h, 149

19 Ibid,
}

\section{HUKMY|Jurnal Hukum}


serta mudah di jangkau oleh semua kalangan serta lebih-lebih dapat meringkan beban MA yang semakin banyak dan menumpuk.

\section{Bentuk Ideal Judicial Review Satu Atap di Mahkamah Konstitusi Sebagai Refleksi Terhadap Problematika Kekuasaan Kehakiman di Indonesia}

Upaya menyatukan praktik judicial review satu atap di MK dapat terus di perjuangkan. Sebab MK memang mempunyai tugas dan fungsi untuk menguatkan konsep negara hukum, Ham dan demokrasi. Disamping itu pembaharuan hukum dapat pula diwujudkan dengan memperkuat konsitusi melalui MK sebagai pengawal tunggal konstitusi. Dengan itu diharapkan tidak ada regulasi yang bertabrakan dengan Konstitusi. ${ }^{20}$ Sebab pada prinsipnya hukum harus berada pada posisi tertinggi di suatu negara dan mampu memberi jaminan keadilan serta kepastian. Karena itu, tentunya tidak mungkin bila wewenang menguji regulasi dibagi dua yakni MK serta MA. ${ }^{21}$ Maka, edialnya lembaga yang berwenang melaksanakan judicial review cukup satu yaitu MK dengan UUD 1945 sebagai batu uji atas semua regulasi yang kedudukannya dibawah UUD.

Di antara beberapa alasan yang menjadikan judicial review tidak ideal bila dilakukan dengan lembaga yang berbeda yaitu:22 1). Praktik pelaksanaan pembagian kekuasaan dapat menimbulkan suatu pertentangan substantif dari masing-masing putusan yang dihasilkan MK dan MA. Guna menghindari hal tersebut, sebaiknya judicial review diserahkan ke MK. Sehingga MA dan MK bisa fokus pada tugas dan wewenang masing-masing. MA fokus pada masalah keadilan bagi warga, sementara MK menjamin terselenggaranya konstitusionalitas dari seluruh regulasi di Indonesia; 2). Jika MK menjadi satu-satunya lembaga yang melakukan judicial review maka akan dengan sendirinya beban menumpuk pada MA dapat di longgarkan.

\footnotetext{
20 Janpatar Simamora, Analisis Yuridis Terhadap Model Kewenangan Judicial Review di Indonesia, Fakultas Hukum Universitas HKBP Nommensen, Vol.25, No.3, Oktober 2013, h. 390

21 Muhammad Ishar Helmi. Penyelesaian Satu Atap Perkara Judicial Review Di Mahkamah Konstitusi. Jurnal Sosial \& Budaya Syar-I FSH UIN Syarif Hidayatullah Jakarta Vol. 6 No. 1 (2019), pp.97-112, DOI: 10.15408/sjsbs.v6i1.10551. h. 105

22 afi', Urgensi Penyatuan Kewenangan Pengujian Peraturan Perundang-undangan oleh Lembaga Peradilan (Judicial Review) Di Indonesia, Jurnal Rechtidee, Vol 11 No. 2, Desember 2016, h. 218 -219.
} 
Berdasarkan teori hukum yang di dalamnya terdapat wewenang, politik dan norma, penyatuatapan kewenangan judicial review di MK, didasari pula dengan alasan berikut: 23

1. Guna meringankan beban perkara di MA yang sangat banyak dan menumpuk, Sehingga MA bisa fokus dalam menangani kasus konkrit pada kasasi dan PK bagi masyarakat pencari adil hal ini didasarkan pada teori wewenang, politik serta hukum. $^{24}$

2. Memberikan rasa keadilan dan kepastian bagi masyarakat karena tidak terdapat lagi perbedaan atau penafsiran serta putusan keduanya saling bertentangan MA dan MK hal ini berdasar teori politik.

3. Rasa efisien serta efektif dari aspek waktu pelaksanaan pengujiannya. Sebab tidak ditemukan lagi aturan yang merintangi MK dalam melaksankan tugasnya berdasarkan Pasal 55 uu no. 7/2020 tentang MK,25

4. Berangkat dari teori kewenangan, politik dan hukum, maksud sera tujuan MK berdasarkan uu no 7/2020 tentang MK yaitu menangani sengketa ketatanegaraan dan konstitusi agar dilaksanakan dengan penuh tanggungjawab sesuai dengan keinginan rakyat serta cita demokrasi.

5. Judicial review di MK sangat terbuka bila dibandingkan praktik judicial review di MA. MK mengikutsertakan para pihak dalam setiap persidanganya. ${ }^{26}$

Dua atap praktik judicial review yang berlangsung banyak menimbulkan adanya silang kewenangan antar lembaga (MA dan MK). Pendapat Mahfud MD, ada dua hal yang patut di catat terkait praktik judicial review di Indonesia, kedua hal tersebut adalah :27 1). Keberadaan MK seharusnya mampu menjamin adanya konsistensi seluruh bentuk regulasi perundang-undangan. Hal ini dapat terwujud bila MK lah yang diberi kewenangan untuk memeriksa dan memutus terkait sengketa perundang-undangan yang ada di Indoneisa. Oleh karena itu, praktik uji materi per-uu di bawah uu terhadap uu yang berada di atasnya akan ideal jika hanya dilakukan oleh MK. Ide ini ada

23 afi', Urgensi Penyatuan Kewenangan Pengujian Peraturan Perundang-undangan oleh Lembaga Peradilan (Judicial Review) Di Indonesia, Jurnal Rechtidee, Vol 11 No. 2, Desember 2016, h. 224

${ }^{24}$ Ibid,

${ }^{25} \mathrm{Ibid}$,

${ }^{26} \mathrm{Ibid}$,

27 Enrico Simanjuntak, 2013, Kewenangan Hak Uji Materil Pada MA RI, Jurnal Hukum dan Peradilan Volume 2 Nomor 3 November 2013, MA RI, Jakarta, h. 342. 
berdampak baik dengan terjadinya konsistensi, singkronisasi serta harmonisasi seluruh regulasi secara linier dalam atap MK.; 2). Sedangkan MA, lebih ideal bila diberi kekuasaan untuk menangani konflik antar-perseorangan, sengketa TUN dan kasasi serta PK. Yang pada prinsipnya menghapuskan kewenangan MA dalam menguji peraturan dibawah uu.

Kategori di atas yang disampaikan Mahfud MD menegaskan bahwa judicial review seluruh peraturan dilakukan terhadap UUD 1945 sebagai batu uji. Tujuannya adalah supaya konsistensi dan konsentrasi terhadap semua semua peraturan per-uu mulai dari paling tinggi, yaitu UUD 1945 hingga yang rendah. ${ }^{28}$ Jika ditelaah dari konteks kenegaraan, MK didesain khusus mengawal konstitusi yang fungsi salah satunya adalah menciptakan keadilan secara konstitusional ditengah-tengah masyarakat. ${ }^{29}$ Sehingga perlu kiranya dirumuskan kembali dalam konsep perubahan UUD 1945 terkait pengujian peraturan yang sejauh ini terbagi menjadi dua lembaga antara MK dan MA dengan cara mengintegrasikan seluruh kewenangan MA yang berkaitan dengan judicial riview menjadi kewenangan MK artinya pengujian uu dilakukan satu pintu oleh MK.

Agar konsepsi di atas dapat terwujud, maka perubahan kelima terhadap UUD 1945 perlu dilakukan yang menempatkan seluruh persoalan peraturan yang ada, mulai UUD 1945 hingga dibawahnya sesuai hierarki perundang-undangan harus diberi kewenangan sepenuhnya ada pada MK.. ${ }^{30}$ karena itulah dalam perubahan UUD 1945 nantinya merubah ketentuan Pasal 24A (1), Pasal 24C (1) UUD 1945 yang kedua pasal di atas berkaitan dengan tugas, fungsi dan kewenangan MA dan MK. Dengan adannya perubahan ke-5 UUD 1945 guna proses JD menjadi satu pintu di MK. Dengan begitu, jaminan efektivitas, efisien, subtantif serta dapat terjamin judicial review yang sesuai dengan kehendak pembaharuan hukum modern. ${ }^{31}$

\footnotetext{
28 Bahtiar, 2015, Problematika Implemantasi Putusan MK Pada Pengujian UU Terhadap UUD, Raih Asa Sukses, Jakarta, h. 102

29 Ibid,

30 Mahkamah Konstitusi, 2004, Cetak Biru Membangun MK Sebagai Institusi Peradilan Konstitusi yang modern dan Terpercaya, MKRI, Jakarta, h iv

31 Moh. Mahfud MD, 2012, Membangun Politik Hukum, Menegakkan Konstitusi, Rajawali Pers, Jakarta, h 135
} 
Dengan menyatukan kewenangan pengujian pada MK, akan berdampak baik bagi masing-masing lembaga mulai dari kesetaraan yang akan terlihat lebih pas artinya tidak ada lembaga yang dipandang lebih rendah karena batu uji yang berbeda atau subjek pengujian yang tidak sama sehingga MK tidak seakan-akan menjadi lembaga peradilan tertinggi kedudukannya secara hukum karena menguji uu dengan UUD 1945 sebagai batu uji. Disisi lain dampak pada MA, Ma dapat terlepas dari ketergantungan kepada MK dalam hal memeriksa dan memutus suatu perkara, seperti halnya praktik dualisme yang selama ini di praktikkan dan telah dibahas di atas. Contoh beberapa kasus yang terjadi selama ini yang membuat MA tidak bebas dalam mengadili, misal jika MA sedang melakukan judicial review, namun uu sebagai batu uji sedang di uji materi oleh MK terhadap UUD 1945, maka MA wajib menunggu hingga MK selesai bersidang dalam arti telah ada keputusan.

Situasi semacam seolah mengindikasikan MA berada dibawah MK kedudukannya baik secara hukum maupun secara kelembagaan, padahal keduanya berada pada derajat yang sama. Itu artinya, jika wewenangan judicial review penuh menjadi kewenangan MK disamping dapat mempermudah terselesaikannya kasus, dapat pula mempertegas bahwa MK serta MA berada pada posisi yang sejajar dalam struktur kelembagaan. MA bisa dikatakan peradilan tertinggi dalam hal persoalan perorangan, sedang $\mathrm{MK}$ adalah lembaga tertinggi dalam hal menciptakan konsistensi seluruh regulasi yang dibuat lembaga legislatif bersama-sama dengan eksekutif supaya tidak lagi ditemukan pertentangan dengan UUD 1945 sebagai konstitusi Indonesia. Manfaat yang lain adalah dapat berimpikasi positif dalam menuntaskan kasus di MA. ${ }^{32}$ Kemudian perkara menumpuk di MA akan menjadi ringan, sehingga, MA bisa menjamin terciptanya keadilan bagi individual yang kongkrit bagi mereka yang mencari rasa keadilan di MA. ${ }^{33}$

\section{KESIMPULAN}

Berdasar pada pembahasan di atas artikel ini dapat disimpulkan sebagai berikut:

1. Diantara persoalan-persoalan yang dapat terjadi dengan adanya dualisme judicial review antara MA-MK adalah prosedur pemeriksaan perkara yang dilakukan MA

\footnotetext{
${ }^{32}$ Zainal Ariffin Hoesein, 2009, Judicial Teview di MA, Rajawali Pers, Jakarta, hlm. 111-112

${ }^{33}$ Antoni Putra, Dualisme Pengujian Peraturan Perundang-Undangan, Jurnal LEGISLASI INDONESIA Vol 15 No.2 - Juli 2018, h, 77
} 
tidak mengedepankan asas transparansi dan hukum acaranya yang tidak terstruktur dengan jelas menjadikan judicial review pada MA banyak menuai kritikan dari masyarakat secara umum. Potensi terjadinya konflik hukum sangat rentan sebab putusan-putusan yang di hasilkan dari masing-masing lembaga terdapat perbedaan secara jelas. Praktik dualisme judicial review bertentangan dengan asas peradilan yang murah cepat dan ringan sebab kewenangan yang ada pada MA tidak hanya menguji peraturan terhadap uu. Menumpuknya beban perkara di MA menjadikan peradilan MA tidak efektif dan efisien sehingga diperlukan kewenangan MK yang penuh sebagai pelaku tunggal judicial review.

2. Bentuk ideal judicial review di Indonesia adalah dengan menjadikan MK sebagai pelaku tunggal kewenagan ini, hal ini akan berdampak baik bagi masing-masing lembaga mulai dari kesetaraan yang akan terlihat lebih pas artinya tidak ada lembaga yang dipandang lebih rendah karena batu uji yang berbeda atau subjek pengujian yang tidak sama sehingga MK tidak seakan-akan menjadi lembaga peradilan tertinggi kedudukannya secara hukum karena menguji uu dengan UUD 1945 sebagai batu uji. Disisi lain dampak pada MA, Ma dapat terlepas dari ketergantungan kepada MK dalam hal memeriksa dan memutus suatu perkara, seperti halnya praktik dualisme yang selama ini di praktikkan dan telah dibahas di atas. disamping dapat mempermudah terselesaikannya kasus, dapat pula mempertegas bahwa MK serta MA berada pada posisi yang sejajar dalam struktur kelembagaan. MA bisa dikatakan peradilan tertinggi dalam hal persoalan perorangan, sedang MK adalah lembaga tertinggi dalam hal menciptakan konsistensi seluruh regulasi yang dibuat lembaga legislatif bersama-sama dengan eksekutif supaya tidak lagi ditemukan pertentangan dengan UUD 1945 sebagai konstitusi Indonesia.

\section{DAFTAR PUSTAKA}

Afi', Urgensi Penyatuan Kewenangan Pengujian Peraturan Perundang-undangan oleh Lembaga Peradilan (Judicial Review) Di Indonesia, Jurnal Rechtidee, Vol 11 No. 2, Desember 2016

Ahmad Kamil. Filsafat Kebebasan Hakim. Jakarta: Kencana Prenada Media Group. 2012 
Andi Suherman. Implementasi Independensi Hakim Dalam Pelaksanaan Kekuasaan Kehakiman. SIGn Jurnal HukumVol. 1, No. 1 (September 2019) 42 - 51e-ISSN: 2685 - 8606 || p-ISSN: 2685 - 8614

Asshiddiqie, Jimly. Format Kelembagaan Negara dan Pergeseran Kekuasaan dalam UUD 1945, UII Press, Yogyakarta, 2005

Bambang Sutiyoso. Pembentukan Mahkamah Konstitusi Sebagai Pelaku Kekuasaan Kehakiman di Indonesia Jurnal Konstitusi, Volume 7, Nomor 6, Desember 2010

Erli Salia, Peran Mahkamah Konstitusi Dalam Mewujudkan Negara Hukum Yang demokratis, (Makalah, Palembang),

I Dewa Gede Palguna, Pengaduan Konstitusional (Constitutional Complaint) Upaya Hukum terhadap Pelanggaran Hak-hak Konstitusional Warganegara, Sinar Grafika: Jakarta, 2013

I Dewa Gede Palguna, Pengaduan Konstitusional (Constitutional Complaint) Upaya Hukum terhadap Pelanggaran Hak-hak Konstitusional Warganegara, (Sinar Grafika: Jakarta, 2013)

Janpatar Simamora, Analisis Yuridis Terhadap Model Kewenangan Judicial Review di Indonesia, Fakultas Hukum Universitas HKBP Nommensen, Vol.25, No.3, Oktober 2013

Jimly Assiddiqie, Perkembangan dan Konsolidasi Lembaga Negara Pasca Reformasi, (Setjen dan kepaniteraan Mahkamah Konstitusi, Jakarta, 2006

Jimly Asshiddiqie, Gagasan Dasar tentang Konstitusi dan Mahkamah Konstitusi dalam Butirbutir Pemikiran dalam Hukum, Memperingati 70 tahun Prof. Dr B. Arief Shiddarta, SH. Penyunting Sri Rahayu Oktoberina dan Niken Savitri, Refika Aditama: Bandung, 2008

Moh Kusnardi dan Harmaily Ibrahim, Pengantar Hukum Tata Negara Indonesia, Pusat Studi Hukum Tata Negara Fakultas Hukum Universita Indonesia, Jakarta: 1983

Moh. Mahfud MD. Rambu Pembatas Dan Perluasan Kewenangan Mahkamah Konstitusi. Jurnal Hukum No. 4 Vol. 16 Oktober 2009

Moh.Mahfud MD,“Kekuasaan Kehakiman Pasca Amandemen UUD 1945,”makalah pada Diskusi Publik tentang Wacana Amandemen Konstitusi yang diseleng garakan oleh Komisi Hukum Nasional (KHN) di Jakarta, tanggal 12 Juni 2008

Muhammad Ishar Helmi. Penyelesaian Satu Atap Perkara Judicial Review Di Mahkamah Konstitusi. Jurnal Sosial \& Budaya Syar-I FSH UIN Syarif Hidayatullah Jakarta Vol. 6 No. 1 (2019), pp.97-112.

Sri Sumantri, Hukum Uji Materiel, Edisi Kedua, Bandung: Alumni, 1997

Sudikno Mertokusumo, Mengenal Hukum Suatu Pengantar, Yogyakarta: Liberty, 1998

Ulin Najihah, Penerapan Sistem Pembuktian Di Mahkamah Konstitusi, (Yogyakarta: Fakultas Hukum Universitas Islam Indonesia, 2008 